\title{
SYNTHESIS OF DIESEL-LIKE HYDROCARBON FROM JATROPHA OIL THROUGH CATALYTIC PYROLYSIS
}

\author{
Bambang Heru Susanto*, Mohammad Nasikin, \\ Ayuko Cheeryo Sinaga, Fransisca \\ Departemen Teknik Kimia, Fakultas Teknik \\ Universitas Indonesia \\ Kampus UI, Depok 16424 \\ email: bambanghs@che.ui.ac.id
}

\begin{abstract}
Due to economical, sosial and ecological reason, several studies have been done in order to obtain alternative fuel sources. In this respect, fermentation, transesterification and pyrolysis if biomass have been proposed as alternative solutions. Among these different approaches, pyrolysis seems to be a simple and efficient method fuel production. Pyrolysis, assisted by solid catalysts, has also been reported and it was recognized that the product selectivity is strongly affected by the presence and the nature of heterogenous catalysts. The catalytic pyrolysis of straight jathropha curcas oil ( $\mathrm{SJO}$ ) over nanocrystalline $\mathrm{NiO} / \mathrm{Al}_{2} \mathrm{O}_{3}$ at $475{ }^{\circ} \mathrm{C}$ was studied. $\mathrm{NiO} / \mathrm{Al}_{2} \mathrm{O}_{3}$ catalyst was used in pyrolysis for purpose of selectively cracking of triglyceride. Nanocrystalline $\mathrm{NiO} / \mathrm{Al}_{2} \mathrm{O}_{3}$ was prepared by simple heating method with polymer solution as growth inhibitor. The liquid product (biooil) were analyzed by GCFID and FTIR, showing the formation of carboxylic acids, paraffins, olefins, and ketone. Measured physical properties of biooil is comparable to those specified for diesel oil.
\end{abstract}

Keywords: SJO, nanocrystalline, simple heating method, catalytic pyrolysis, biooil

\begin{abstract}
Abstrak
Adanya pertimbangan keekonomian, sosial, dan ekologi, menyebabkan dilakukannya penelitian guna mendapatkan sumber bahan bakar alternatif. Berkaitan dengan hal tersebut, maka reaksi-reaksi seperti permentasi, transesterifikasi dan pirolisis dari biomasa telah digunakan sebagai alternatif solusi. Diantara pendekatan-pendekatan yang berbeda tersebut, pirolisis merupakan metode yang sederhana dan efesien untuk menghasilkan bahan bakar. Pirolisis, yang dibantu dengan katalis padat, telah juga dilaporkan dan diketahui bahwa selektifitas produknya sangat dipengaruhi oleh kehadiran dan sifat dari katalis-katalis heterogen yang digunakan. Pirolisis berkatalis dari minyak jarak pagar (straight jathropha curcas oil, SJO) melalui nanokristal $\mathrm{NiO} / \mathrm{Al}_{2} \mathrm{O}_{3}$ pada suhu $475{ }^{\circ} \mathrm{C}$ telah dilakukan percobaanya. Katalis $\mathrm{NiO} / \mathrm{Al}_{2} \mathrm{O}_{3}$ digunakan dalam pirolisis dengan tujuan untuk perengkahan selektif dari trigliserida. Nanokristal $\mathrm{NiO} / \mathrm{Al}_{2} \mathrm{O}_{3}$ dibuat dengan menggunakan metode simple heating dengan pelarut polimer sebagai penghambat pertumbuhan. Produk cair yang dihasilkan (biooil) telah dianalisa dengan menggunakan GC-FID dan FTIR, memperlihatkan adanyanya gugus asam-asam karboksilat, parafin, olefin dan keton. Sifat fisik yang diukur dari biooil dapat diperbandingkan kesetaraanya dengan spesifikasi dari minyak solar.
\end{abstract}

Kata kunci: SJO, nanokristal, metode simple heating, pirolisis berkatalis, biooil.

*corresponding author 


\section{Introduction}

Nowadays, there are many ways to generate green energy. Based on the renewability of the resources, energy can be classified into 2 major categories, namely renewable energy (such as solar power, wind, water, geothermal, biomass, etc) and non-renewable energy (most resources classified in this category are fossil fuels, such as petroleum, coal, and natural gas) (Olasula et al., 2009). Fossil fuels are highly commercial in global scale, especially petroleum for which the demand steadily grows from time to time. On the contrary, the production rate of fossil fuels such as petroleum has been declining in these recent years. One of efforts to overcome this issue is through the cracking vegetable oil using heterogeneous catalyst.

In this respect, fermentation, transesterification, and pyrolysis of biomass, industrial, and domestic wastes, have been proposed as alternative solutions for the increasing energy demand and environmental awareness. Among these different approaches, pyrolysis seems to be a simple and efficient method for fuel production. The pyrolysis of different triglycerides was used for fuel supply in different countries during the First and Second World Wars. These hydrocarbons were used as raw materials for gasoline and diesel-like fuel production in a cracking system similar to the petroleum process now used. Since then several studies on vegetable oil pyrolysis as an alternative method to obtain chemicals and fuels have been reported in the literature. Pyrolysis, assisted by solid catalysts, has also been reported and it was recognized that the product selectivity is strongly affected by the presence and the nature of heterogeneous catalysts (Maher and Bressler, 2007).

In recent years, the utilization of $\gamma$ alumina catalyst was able to produce the same level of hydrocarbon as can be found in gasoline, diesel and kerosene (Wijanarko et al., 2006). Moreover, the effect from adding $\mathrm{B}_{2} \mathrm{O}_{3}$ into zeolite for decarboxilation of POME (Palm Oil Methyl Ester) produced hydrocarbon product which $\mathrm{C}$ range was equivalent to gasoline (Setiadi and Mailisia, 2006). However, a catalyst material in a conventional form is less effective. One of the reason is caused by low catalyst activities that unable to crack the reactants into conventional fuel fraction. Moreover, the activities of catalysts are limited by formation of cokes, and the pores of the catalyst covered by cokes formation.

Nowadays, nanomaterials have become popular option to strengthen the characteristics of catalyst. For instance, Li et al. (2008) showed that utilization of $\mathrm{NiO}$ as nanocatalyst for pyrolysis of biomass improved their activity and selectivity compared to that of micro NiO. As a support, $\mathrm{Al}_{2} \mathrm{O}_{3}$ can increase the performance of catalyst due to its catalytic characteristic in a cracking process (Maher and Bressler, 2007).

\section{Methodology}

This study was conducted in two steps namely the preparation and characterization of nanocrystaline $\mathrm{NiO} / \mathrm{Al}_{2} \mathrm{O}_{3}$, and synthesis of diesel-like hydrocarbon over $\mathrm{NiO} / \mathrm{Al}_{2} \mathrm{O}_{3}$ catalyst in a catalytic pyrolysis reactor.

\subsection{Preparation of Nanocrystalline $\mathrm{NiO} / \mathrm{Al}_{2} \mathrm{O}_{3}$}

Nanocrystalline nickel oxide on alumina support was prepared by simple heating method adopted from Abdullah and Khairurrijal (2009). These catalysts were assigned as $5 \mathrm{wt} \%$ NiO/Alumina. For each catalys, required amounts of the precursor salts, i.e., $\mathrm{Al}\left(\mathrm{NO}_{3}\right)_{3} \cdot 9 \mathrm{H}_{2} \mathrm{O}$ and $\mathrm{Ni}\left(\mathrm{NO}_{3}\right)_{2} \cdot 6 \mathrm{H}_{2} \mathrm{O}$ were dissolved in deionized water and added to the support dropwise with constant stirring followed by drying in an oven at 120 ${ }^{\circ} \mathrm{C}$ overnight. Polymer solution, as continuous media, was used to avoid agglomeration of particle group of catalyst. Therefore the polymer should be remained until the end of the process. Finally the solution was heated in furnace to vaporize the PEG and to produce the final nanocrystalline $\mathrm{NiO} / \mathrm{Al}_{2} \mathrm{O}_{3}$. Flow chart of preparation of nanocrystalline $\mathrm{NiO} / \mathrm{Al}_{2} \mathrm{O}_{3}$ is described in Figure 1.

\subsection{Catalytic Pyrolysis Experiment}

The catalytic pyrolysis experiments were conducted using a self-designed $50 \mathrm{~mL}$ batch reactor system. Figure 2 shows a schematic diagram of the apparatus. A known amount of $\mathrm{NiO} / \mathrm{Al}_{2} \mathrm{O}_{3}$ catalyst was charged into the reactor. Cracking reactions were carried out at $475{ }^{\circ} \mathrm{C}$ (atmospheric pressure) with internal temperature being measured by a thermocouple. The reactor was purged with nitrogen during experiment (90 $\mathrm{min}$ ) to remove any oxygen that might have been dissolved and present in the straight jathropha curcas oil (SJO). The gas product 


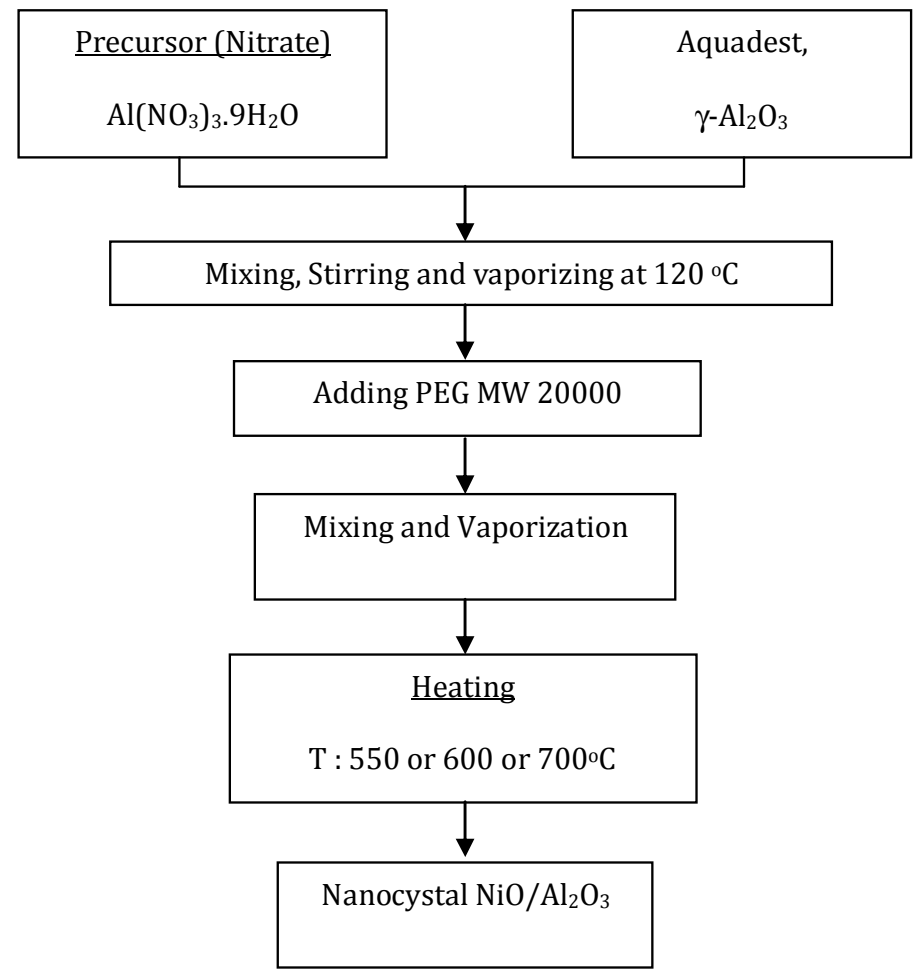

Figure 1. Catalyst preparation flow chart

was condensed and collected. The liquid product (biooil) was collected and analyzed.

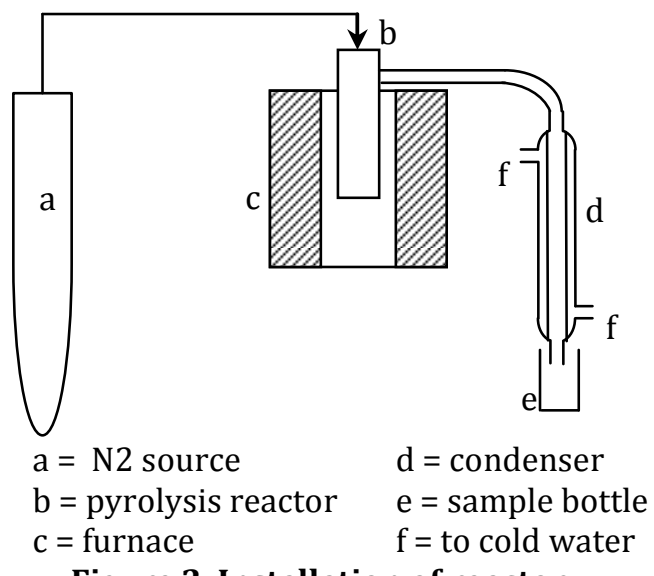

Figure 2. Installation of reactor

\subsection{Characterizations}

The surface area, pore volume and average pore radius of the catalysts were determined by the BET (Brunauer-Emmett-
Teller) method. Identification of crystalline phase and its distribution in the catalyst was performed using X-ray diffraction (XRD). Analysis of the pyrolysis products (biooil) were performed using FT-IR (Fourier Transfrom Infra Red) and GC-FID (Flame Ionization Gas Chromatography Detector). Physical properties of biooil (product of catalytic pyrolysis), e.g. density and viscosity, were measured as well.

\section{Results and Discussions 3.1 Catalysts Characterization}

BET specific surface area and pore size of the samples are listed in Table 1. It can be seen that BET surface area of the catalysts decrease with increasing temperature. Increasing temperature led to more rapid PEG vaporization and sintering of catalyst which occured during reaction. These results correspond with those informed by Abdullah et al. (2008) and Garcia et al. (2001).

Table 1. BET Charazterization Results

\begin{tabular}{ccccc}
\hline Catalyst & $\begin{array}{c}\text { Heating } \\
\text { Temperature }\left({ }^{\circ} \mathrm{C}\right)\end{array}$ & $\begin{array}{c}\text { Heating time } \\
(\text { minute) }\end{array}$ & $\begin{array}{c}\text { Surface area } \\
\left(\mathrm{m}^{2} / \mathrm{g}\right)\end{array}$ & $\begin{array}{c}o \\
\text { Pore size }(\mathrm{A})\end{array}$ \\
\hline Sample 1 & 550 & 30 & 12.98 & 103.2 \\
Sample 2 & 600 & 30 & 10.21 & 133.3 \\
Sample 3 & 700 & 30 & 14.23 & 149.9 \\
Sample 4 & 600 & 60 & 8.1 & 215.3 \\
\hline
\end{tabular}



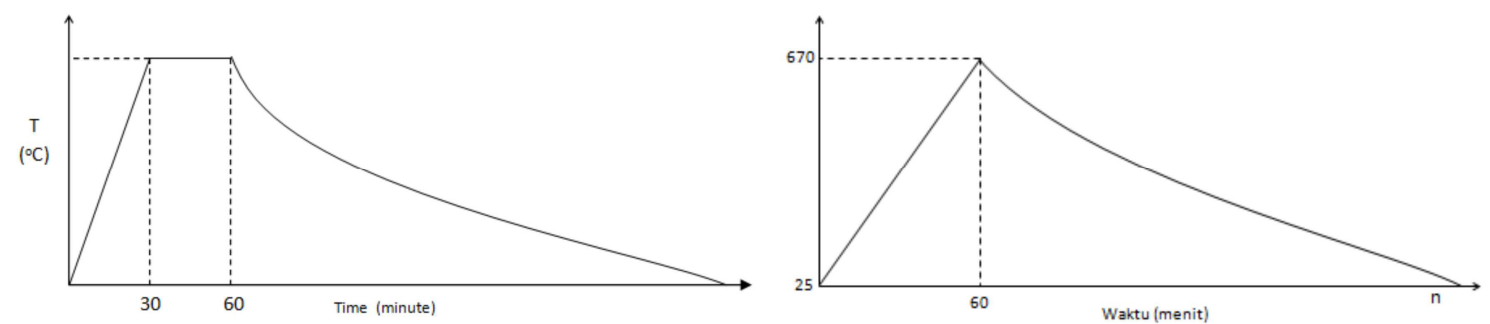

Figure 3. Heating profile of catalysts preparation (a) sample 1 and 2 (b) sample 3

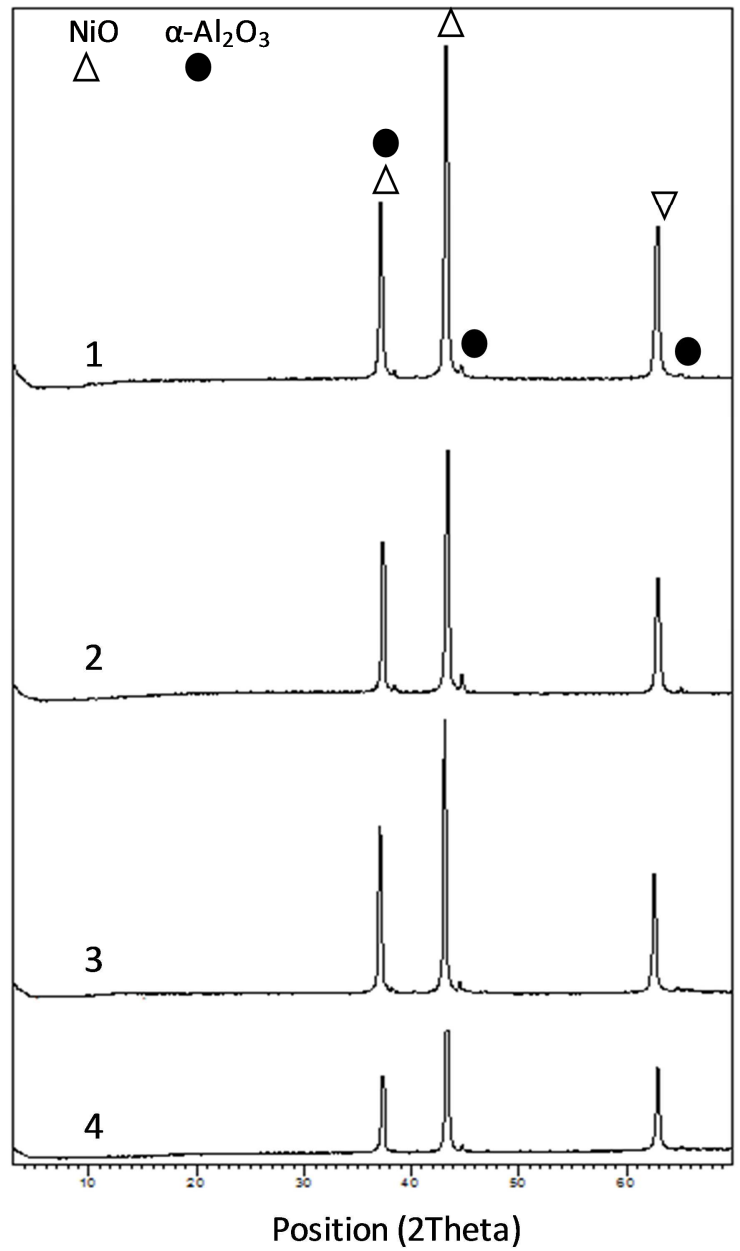

Figure 4. XRD diffractogram: (1) sample 1, (2) sample 2, (3) sample 3, (4) sample 4.

The result of Sample 3 was different with the other ones due to the differences in the heating profile as shown in Figure 3. For Sample 3 the time of heating was not kept constant, and this caused the sintering that occurred on the catalyst to beweaker than other samples. XRD characterization results are shown in Figure 4. Based on XRD diffractograms, it can be seen that $\mathrm{NiO}$ and $\mathrm{Al}_{2} \mathrm{O}_{3}$ crystals were formed. Table 2 shows the results of crystallite size of catalyst, where the increasing temperature and time resulted in larger crystal sizes. Higher temperature accelerated PEG vaporization which was used as growth inhibitor, while a longer heating time could provide an opportunity to crystal growth. Therefore, sintering will occur faster in formation of larger crystal. However, the different case happened on Sample 3, which was caused by the different heating profiles of Sample 1 and 2 as shown in Figure 3. 
Table 2. Crystallite Size of Catalysts

\begin{tabular}{cc} 
Sample & Crystal size (nm) \\
\hline 1 & 156.800 \\
2 & 174.330 \\
3 & 153.000 \\
4 & 191.554 \\
\hline
\end{tabular}

\subsection{Biooil Characterization}

The visual appearances of pyrolytic products (biooil) are yellow, tawny, and blackish brown as seen in Figure 5. Pyrolysis of SJO was performed with three sample catalysts which had the smaller crystal size, namely Sample 1, 2, and 3. Tables 3 and 4 show the results of density and viscosity measurements. The results of density and viscosity measurement confirmed that cracking occurred and the values showed in the range of diesel fuel. It was proved by the decreasing of those two physical properties compared with SJO ones. The use of catalysts affected in reduction of density and viscosity of biooil, rather than that without catalyst.

Crystallite size of catalysts affected the result of the physical properties of biooil products. Decreasing crystal size tended to reduce density and viscosity of biooil. This relates to the enhancement of material properties when its size became smaller. Surface area is also one of the factors of the decreasing density. Higher surface area caused jatropha oil molecules to be more reactive and gives the higher cracking effect.
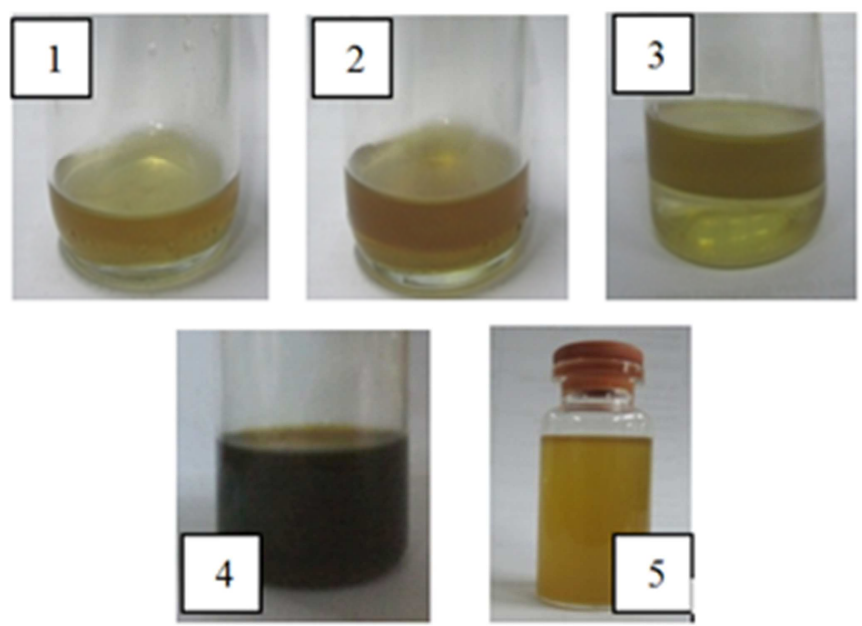

Figure 5. Product of biooils (1) Sample 1, (2) Sample 2, (3) Sample 3, (4) without catalysts, (5) SJO

Table 3. Density of Biooil

\begin{tabular}{|c|c|c|c|c|}
\hline \multirow{3}{*}{ Catalysts } & \multicolumn{4}{|c|}{$\rho(\mathrm{gr} / \mathrm{mL})$ at $25^{\circ} \mathrm{C}$} \\
\hline & \multicolumn{2}{|c|}{ Biooil } & \multirow{2}{*}{ Diesel } & \multirow{2}{*}{ SJO } \\
\hline & With catalyst & Without catalysts & & \\
\hline Sample 1 & 0.8581 & & & \\
\hline Sample 2 & 0.8397 & 0.8990 & 0.822 & 0.9107 \\
\hline Sample 3 & 0.8274 & & & \\
\hline
\end{tabular}

Table 4. Viscosity of Biooil

\begin{tabular}{|c|c|c|c|c|}
\hline \multirow{3}{*}{ Catalysts } & \multicolumn{4}{|c|}{$\mu(\mathrm{cp})$ at $25^{\circ} \mathrm{C}$} \\
\hline & \multicolumn{2}{|r|}{ Biooil } & \multirow{2}{*}{ Diesel } & \multirow{2}{*}{ SJO } \\
\hline & With catalyst & Without catalysts & & \\
\hline Sample 1 & 2.0974 & \multirow{3}{*}{15.8598} & \multirow{3}{*}{3.5} & \multirow{3}{*}{40.5} \\
\hline Sample 2 & 2.1683 & & & \\
\hline Sample 3 & 1.7500 & & & \\
\hline
\end{tabular}


In order to identify biooil a GC-FID analysis was carried out. Among the classes of compounds formed (Table 5), diesel-like hydrocarbon was identified. The result of GCFID shows that cracking process was selective towards $\mathrm{C}_{12}-\mathrm{C}_{18}$, diesel fraction with the most high percentage as many as $54.16 \%$.

Table 5. GC-FID results

\begin{tabular}{ccc}
\hline $\begin{array}{c}\text { Carbon } \\
\text { chain }\end{array}$ & $\begin{array}{c}\text { Yield } \\
\text { (\% Wt.) }\end{array}$ & Product \\
\hline $\mathrm{C}_{1}-\mathrm{C}_{5}$ & 0.05 & Gas \\
$\mathrm{C}_{5}-\mathrm{C}_{11}$ & 16.25 & Gasoline \\
$\mathrm{C}_{11}-\mathrm{C}_{12}$ & 8.91 & Kerosene \\
$\mathrm{C}_{12}-\mathrm{C}_{18}$ & 54.16 & Diesel \\
$\mathrm{C}_{18}-\mathrm{C}_{25}$ & 33.48 & Lubricant \\
$\mathrm{C}_{21}-\mathrm{C}_{27}$ & 20.16 & Fuel oil \\
\hline
\end{tabular}

Figure 6 shows FTIR spectra obtained for SJO, biooil and diesel oil. Each spectrum was normalized by the intensity of the absorption band centered at $2930 \mathrm{~cm}^{-1}$ (the strongest band). Characteristic vibrational modes are observed at $3080 \mathrm{~cm}^{-1}(\mathrm{CH}$ stretching, olefinic), $2850-2990 \mathrm{~cm}^{-1}(\mathrm{CH}$ stretching, aliphatic), $1710 \mathrm{~cm}^{-1} \quad(\mathrm{C}=0$ stretching), and $1642 \mathrm{~cm}^{-1}$ ( $\mathrm{C}=\mathrm{C}$ stretching, olefinic). The products of SJO cracking present some absorption features that are not observed in the other two oil cracking products, e.g. the absorption at 1700-1720 $\mathrm{cm}^{-1}$ that is characteristic of keton. It is also observed for SJO and biooil. The absorptions at 1285 and $1240 \mathrm{~cm}^{-1}$, indicating the presence of carboxylic acids. It is worth mentioning that no vibrational feature, characteristic of aromatic compounds, was observed in the FTIR spectra, which is in good agreement with what was observed in the GC-FID analysis.
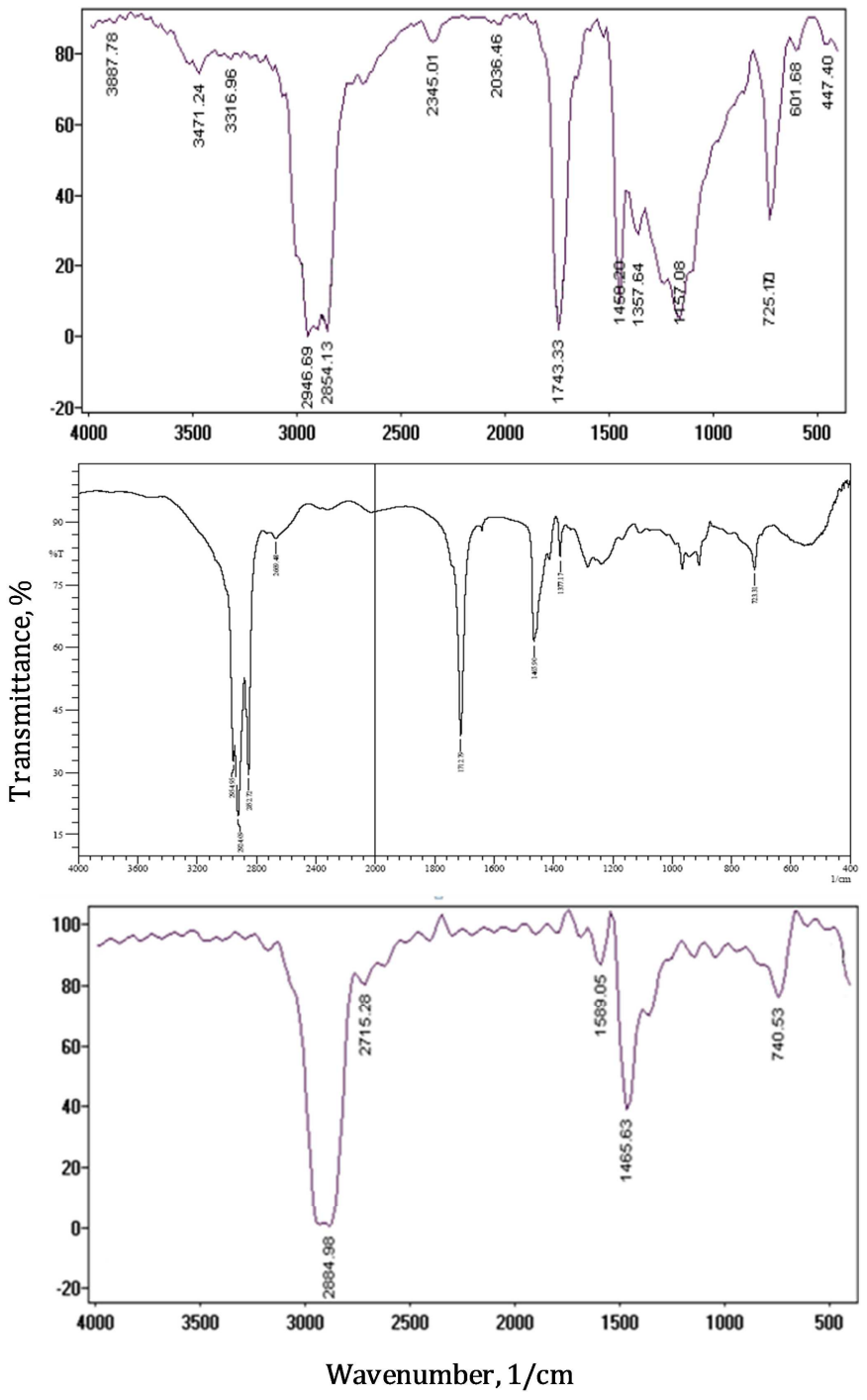

Figure 6. FT-IR spectrum (1) SJO, (2) biooil, (3) diesel fuel 


\section{Conclusions}

In this research, $\mathrm{NiO} / \mathrm{Al}_{2} \mathrm{O}_{3}$ catalysts were prepared by simple heating method with polymer solution as a growth inhibitor. Characterization of catalysts have shown that the smallest crystal catalyst size is $153 \mathrm{~nm}$ which prepared at $700{ }^{\circ} \mathrm{C}$ when the heating temperature was not keep constant. Catalytic pyrolysis of $\mathrm{SJO}$ over $\mathrm{NiO} / \mathrm{Al}_{2} \mathrm{O}_{3}$ was carried out in batch reactor. The experimental conditions were $475{ }^{\circ} \mathrm{C}$ for average reaction temperature and 90 minutes for residence time. These condition led to dominant yield of $54.16 \%$ of diesel fraction $\left(\mathrm{C}_{12}-\mathrm{C}_{18}\right)$. Measured physical properties of biooil is comparable to those specified for diesel oil, i.e. the densities of biooil were in the range of diesel fuel specifications, but the viscosities of biooil were still lower than criteria of diesel fuel specifications.

\section{Acknowledgement}

This research is funded by Hibah Riset Strategis Nasional Universitas Indonesia 2011 (RSN-UI).

\section{References}

Abdullah, M.; Khairurrijal; Maruly, A. R.; Liherlinah; Sanny, M., Sintesis dan pengujian katalis nanokristalin $\mathrm{Cu} / \mathrm{ZnO} / \mathrm{Al}_{2} \mathrm{O}_{3}$ dengan metode pemanasan dalam larutan polimer untuk aplikasi konversi metanol menjadi hidrogen, Jurnal Nanosains dan Nanoteknologi, 2008, 1, 2-10.

Abdullah, M.; Khairurrijal, Review: Sintesis nanomaterial, Jurnal Sains dan Teknologi, 2009, 2, 1-9.
Garcia, M. A. V.; Platero E. E.; Colinas, J. M. F.; Arean, C. O., Variation of surface area during isothermal sintering of mesoporous gammaalumina, Thermochimica Acta, 1985, 90(1), 195-199.

Li, J.; Yan, R.; Xiao, B.; Liang, D. T.; Lee, D. H., Preparation of nano-NiO particles and evaluation of their catalytic activity in pyrolyzing biomass components, Energy \& Fuels, 2008, 22(1), 16-23.

Maher, K. D.; Bressler, D. C., Pyrolysis of trygliceride materials for the production of renewable fuels and chemicals, Bioresource Technology, 2007, 98(12), 2351-2368.

Olusula, J. O.; Adediran, M. M.; Oluseyi, A. K.; Ajao, U. L, Processing of triglycerides to diesel range hydrocarbon fuels: easily practicable small scale approach, Energy and Environment, 2009, 20(8), 1325-1340.

Setiadi; Mailisia F., Proses Katalitik Sintesis Hidrokatbon Fraksi Bensin dari Minyak sawit Menggunakan Katalis $\mathrm{B}_{2} \mathrm{O}_{3} /$ Zeolit, Proceeding Seminar Nasional Masyarakat Katalis Indonesia (MKICS) Indonesian Catalyst Society, Depok, 26-27 June 2006, pp. 94-98.

Wijanarko, A.; Mawardi, D. A.; Nasikin, M., Produksi biogasoline dari minyak sawit melalui reaksi perengkahan katalitik dengan katalis $\gamma$-alumina, Makara Technology Series, 2006, 10(2), 51-60. 